Gut, 1971, 12, 929-932

\title{
High liver glycogen in hereditary fructose intolerance
}

\author{
A. R. R. CAIN AND BRENDA E. RYMAN \\ From the Children's Department, Newcastle General Hospital, and the Department of Biochemistry, Royal Free \\ Hospital School of Medicine, London
}

SUMMARY A case of hereditary fructose intolerance is reported in a girl aged 2 years at the time of her death. She had apparently progressed normally until the age of 14 months. At 19 months she was admitted to hospital with failure to thrive, hepatomegaly, and superficial infections. Investigations revealed hypoglycaemia, persistent acidosis, aminoaciduria, and a high liver glycogen level which suggested that she had glycogen storage disease. There was also some evidence of malabsorption.

At necropsy the liver enzyme estimations showed that fructose 1-phosphate aldolase activity was absent and that fructose 1,6-diphosphate aldolase activity was reduced. Hereditary fructose intolerance and glycogen storage disease have been confused in the past on clinical grounds, but a high liver glycogen level has not previously been reported in hereditary fructose intolerance.

Hereditary fructose intolerance is due to a lack of the enzyme fructose 1-phosphate aldolase (Fig.). Children with this condition thrive in the absence of a dietary source of fructose (eg, sucrose) but in the presence of the monosaccharide and its impaired metabolism, fructosaemia, fructosuria, hypoglycaemia, hepatosplenomegaly, aminoaciduria, glycosuria, proteinuria, and acidosis may occur (Froesch, 1966). Once the condition is recognized, exclusion of fructose from the diet enables the child to develop normally.

The present communication describes a girl who at necropsy was found by enzyme assay to have had hereditary fructose intolerance and in whom this diagnosis was not contemplated in life because of a high biopsy liver glycogen level, which suggested that she had glycogen storage disease.

\section{Case Report}

The proposita was the only child of healthy, unrelated parents and had thrived until the age of 14 months (weight $9.5 \mathrm{~kg}$ ). For the next five months she had recurrent vomiting, some diarrhoea, persistent anorexia, and lost weight. On admission at 19 months she was wasted $(7 \cdot 3 \mathrm{~kg})$. She had bilateral conjunctivitis, angular stomatitis, a nasal discharge, and an extensive nappy rash. The liver was enlarged to 5 $\mathrm{cm}$ below the right costal margin.

Received for publication 5 July 1971 .

\section{Investigations}

Total blood sugar was $44 \mathrm{mg} / 100 \mathrm{ml}$ (ferricyanide method); plasma bicarbonate $10 \mathrm{~m}$-equiv/1; haemoglobin $11.8 \mathrm{~g} / 100 \mathrm{ml}$ with a hypochromic blood film and serum iron of $73 \mu \mathrm{g} / 100 \mathrm{ml}$. An occasional trace of reducing substances was detected in the urine with Clinitest tablets, but was negative to glucose oxidase. Urine chromatography was negative for sugars but revealed aminoaciduria.

Malabsorption was suggested by a faecal fat of $4.3 \mathrm{~g} /$ day, a whole blood folate of $32 \mathrm{ng} / \mathrm{ml}$, a retarded bone age, dilatation of small bowel, and a flat oral glucose tolerance curve. Two attempts at a jejunal biopsy were unsuccessful. Galactosaemia was excluded by demonstration of normal galactose 1-phosphate uridyl transferase in the child's erythrocytes.

Glycogen storage disease was also a possibility in view of the hypoglycaemia, persistent acidosis, and large liver. Glucagon stimulation on two occasions $(0.25 \mathrm{mg}$ intramuscularly) gave a normal blood sugar rise. A repeat glucose tolerance gave a flattened curve with high lactate levels of $30-40 \mathrm{mg} / 100 \mathrm{ml}$.

She was discharged on a gluten-free diet with iron and vitamin supplements. On re-admission, aged 2 years (weight $8.5 \mathrm{~kg}$ ), her liver was still enlarged and the plasma bicarbonate remained low at 7.5-10 m-equiv/litre.

An oral galactose tolerance test produced a moderate rise in total blood sugars while blood 929 


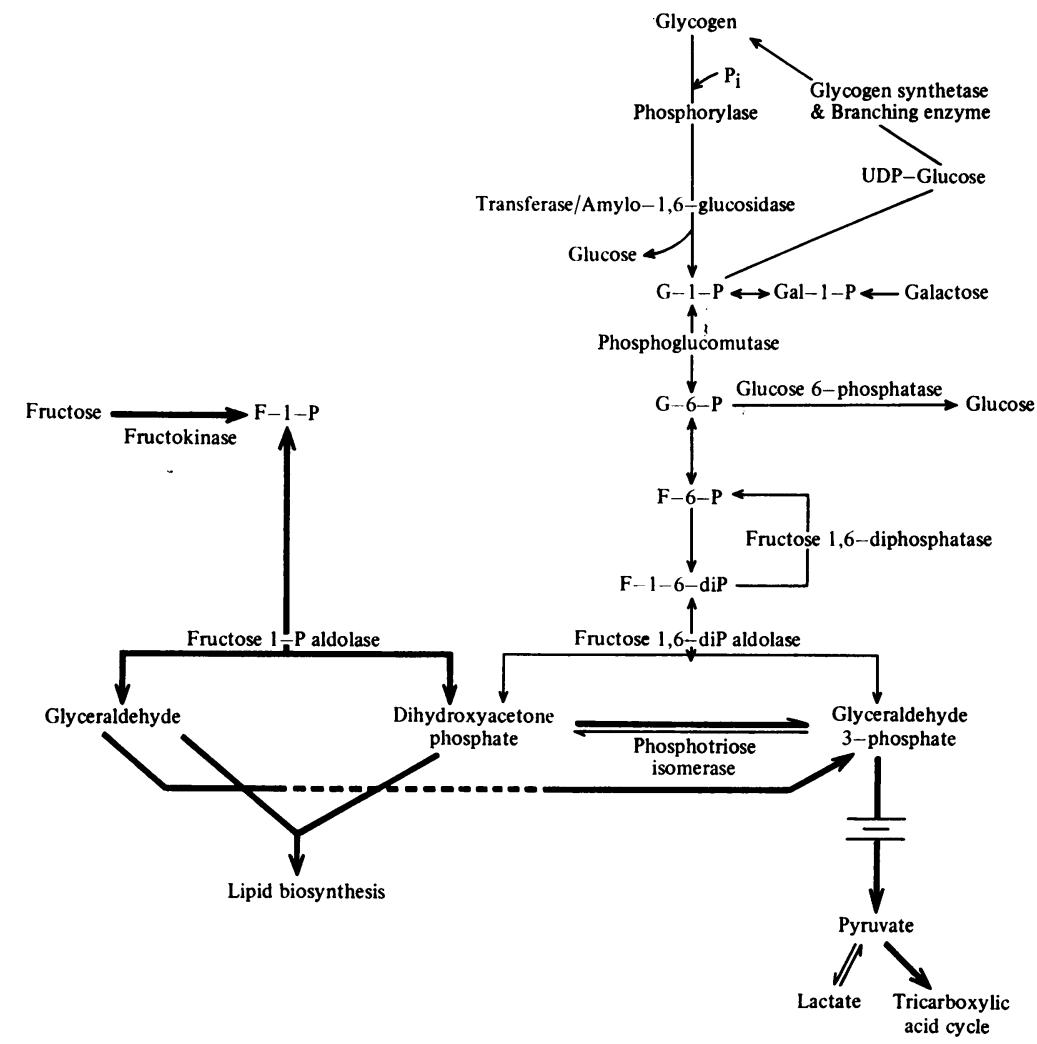

Fig. The main pathways of fructose metabolism and the interrelationship with glycogen metabolism. The main pathway whereby fructose is probably metabolized is shown in heavy lines.

lactates rose from 30 to $50 \mathrm{mg} / 100 \mathrm{ml}$. A liver biopsy showed $10 \%$ of glycogen by weight, though the glucose 6-phosphatase activity was normal. The leucocyte phosphorylase activity was also normal.

From these results glycogen amylo-1, 6-glucosidase (debranching enzyme) deficiency appeared likely, though the normal response to glucagon was puzzling.

Twelve days after being sent home for the Christmas holidays she was brought into hospital, moribund. She had had little nourishment except glucose drinks and she had had many loose stools (weight $7 \cdot 1 \mathrm{~kg}$ ). She died later that day.

At necropsy (Dr W. Aherne) she was found to have aspirated vomit and a terminal bronchopneumonia was present. The liver was not obviously enlarged but it was pale yellow due to fatty infiltration.

A piece of liver removed within an hour of death and placed immediately in the deep freeze, together with the small piece of biopsy tissue remaining, were further investigated. The necropsy liver sample was analysed for the presence of enzymes whose absence is known to be associated with the various types of glycogen storage diseases in which high liver glycogen is observed and which have clinical features in

\begin{tabular}{|c|c|c|}
\hline Specimen & Sample & Normal \\
\hline $\begin{array}{l}\text { Biopsy } \\
\text { Glycogen level \% } \\
\text { Glucose 6-phosphatase }^{\mathrm{b}} \\
\text { Phosphorylase }^{\mathrm{c}}\end{array}$ & $\begin{array}{c}11.6 \\
10.4 \\
122.5^{1}\end{array}$ & $\begin{array}{l}1-4 \\
5-10 \\
22\end{array}$ \\
\hline $\begin{array}{l}\text { Necropsy } \\
\text { Glycogen level \%a } \\
\text { Glucose 6-phosphatase }^{\mathrm{b}} \\
\text { Phosphorylase }^{\mathrm{c}} \\
\text { Lysosomal a-glucosidase (acid } \\
\text { maltase) } \\
\text { Amylo-1,6-glucosidase }\end{array}$ & $\begin{array}{l}0.2 \\
9 \cdot 4 \\
21 \cdot 7 \\
\\
0.67 \\
1.05\end{array}$ & $\begin{array}{l}1-4 \\
5-10 \\
22 \\
\text { Around } 0.7 \\
\text { Around } 0.9\end{array}$ \\
\hline $\begin{array}{l}\text { Aldolase activity } \\
\text { With fructose 1-phosphate as } \\
\text { substrate } \\
\text { With fructose 1,6-diphosphate as } \\
\text { substrate }\end{array}$ & 1.59 & 0.92 \\
\hline
\end{tabular}

Table Analyses of biopsy and necropsy liver samples

${ }^{1}$ This high result almost certainly reflects weighing inaccuracy due to availability of less than $5 \mathrm{mg}$ of tissue in this assay; the enzyme is clearly active.

b, d, e, and c absent respectively in types I, II, III, VI glycogen storage diseases. All enzyme activities are expressed as $\mu$ moles substrate converted $\mathrm{min} / \mathrm{g} /$ wet weight of liver. For details of methods for $\mathrm{a} c \mathrm{~d}$ and e see Gruener, McArdle, Ryman, and Weller (1968), and for ${ }^{\mathrm{b}}$ see Ricketts (1963). 
common with those already described in this case (Dickens, Randle, and Whelan, 1968).

The Table shows that the glycogen level of the necropsy liver was low, while the enzyme activities examined were all normal. The original liver biopsy was therefore re-analysed for glycogen content and found to have $11.6 \%$ glycogen.

At this stage it was felt that the diagnosis of glycogen storage disease had been excluded despite the high glycogen level. Reflection on the clinical symptoms strongly suggested similarities to those described for hereditary fructose intolerance. Fructose 1-phosphate aldolase and fructose 1,6-diphosphate aldolase activities were therefore examined in the liver from this child ${ }^{1}$. A control liver biopsy from a child who was suspected of having glycogen storage disease was investigated at the same time and under identical conditions. No fructose 1-phosphate aldolase activity was found in the necropsy liver sample while the level of fructose 1,6-diphosphate aldolase was less than $50 \%$ that of the control. The results are presented in the Table.

\section{Discussion}

A possible criticism of these results is that the liveraldolase assays were done on a postmortem liver specimen and compared to those in a liver 'biopsy'. However, the normal levels of the labile enzymes glucose 6-phosphatase and phosphorylase in the necropsy specimen indicates that the necropsy liver material was strictly comparable to the biopsy control. In addition, aldolase is not a markedly fragile enzyme.

Hereditary fructose intolerance commonly presents in infancy with the introduction of sucrosesupplemented milk. Indeed a number of case reports tell of observant mothers discovering that while their children could not tolerate ordinary sugar they would thrive with glucose. It is all the more remarkable that our patient had presented no overt problem until the age of 14 months since she had previously been fed on a milk preparation which has a particularly

\footnotetext{
${ }^{1}$ The cuvette contained in a total volume of $3.02 \mathrm{ml}: 1.25 \mathrm{ml} 0.5 \mathrm{M}$ Tris buffer, $p \mathrm{H} 8.0 ; 0.25 \mathrm{ml} \mathrm{MgCl}_{2}(1 \mathrm{mM}) ; 0.25 \mathrm{ml}$ NADH (1 mM prepared in 1,000-fold diluted commercial mercaptoethanol); $0.01 \mathrm{ml}$ freshly prepared triose phosphate isomerase (Sigma rabbit-muscle enzyme diluted 10 -fold with $0.5 \mathrm{M}$ Tris buffer, $p \mathrm{H} 8.0$ ); $0.01 \mathrm{ml}$ freshly prepared glycerophosphate dehydrogenase (Sigma, 20-fold diluted with $0.5 \mathrm{M}$ Tris buffer, $\mathrm{pH} 8.0$ ); $0.25 \mathrm{ml}$ fructose 1 -phosphate (1 mM) or $0.25 \mathrm{ml}$ fructose 1,6 -diphosphate $(1 \mathrm{mM})$. The reaction was started by the addition of $0.2 \mathrm{ml}$ liver homogenate $(10 \mathrm{mg} / \mathrm{ml})$ prepared in $50 \mathrm{mM}$ Tris buffer, $p \mathrm{H} \mathrm{8} \cdot 0$,containing $0.005 \mathrm{M}$ EDTA. The homogenate is retained in ice for $10 \mathrm{~min}$ before use. The absorption at $340 \mathrm{~nm}$ was followed for $20 \mathrm{~min}$. A blank correction was applied in which the appropriate substrate was omitted from the mixture since very slight drops in optical density at $340 \mathrm{~nm}$ occurs in the presence of the homogenate, presumably due to endogenous substrates or oxidation by air of the NADH.
}

high sucrose content (Nestlé's). Another unusual feature was our failure to find fructosuria, though a trace of reducing substances was found on three occasions.

A further atypical finding was the high concentration of liver glycogen in the needle biopsy specimen. This has not, to our knowledge, hitherto been reported in this condition, though the clinical similarity to glycogen storage disease has often been mentioned. A few previous reports state that the glycogen level is normal. The reason for the elevated glycogen level is not clear although the diminished glycogenolysis and associated hypoglycaemia have been attributed to several factors. Inhibition of phosphoglucomutase by fructose 1-phosphate has been suggested although this mechanism has been queried. The lack of inorganic phosphate (presumably sequestered in patients with hereditary fructose intolerance as fructose 1-phosphate) has also been evoked as a mechanism involved in the decreased glycogenolysis, since the primary step of glycogen degradation involves phosphorolysis by phosphorylase with the production of glucose 1-phosphate. Diminished cellular levels of ATP (as a result of fructose phosphorylation) with subsequent diminution of gluconeogenesis in the liver has also been suggested as a possible explanation for the decreased glucose production by the liver. All these speculations (see Froesch, 1966), however, still lack fully convincing experimental backing and the complete biochemical effects of fructose 1-phosphate aldolase deletion is not known. The very low liver glycogen level at necropsy in this case is explained by the cachetic state at the time of death and by the fact that she had had no fructose-containing foods for some days before her death.

The diminished level of fructose 1,6-diphosphate aldolase seen in this patient and reported by others (Hers and Joassin, 1961) still raises the question as to whether fructose 1-phosphate aldolase and fructose 1,6-diphosphate aldolase activities are due to two separate catalytic proteins or whether they represent two activities of the same enzyme protein, one of which is totally, and the other partially, lost in hereditary fructose intolerance. The possibility that fructose 1-phosphate inhibits fructose 1,6-diphosphate aldolase has also been considered (Froesch, 1966).

It is possible that the flat glucose tolerance curves observed in this child may reflect a malabsorptive state. Evidence exists that fructose is absorbed, at least in part, by active intestinal transport (Gracey, Burke, and Oshin, 1970), and it is known that fructose 1-phosphate aldolase is normally present in the intestinal mucosa (Kohlin and Mehlin, 1968). It has also been shown that fructose 1-phosphate accumu- 
lates in the intestinal mucosa in this condition (Köhlin and Melin, 1968) and it is reasonable to suppose that the increased level of this sugar phosphate might lead to secondary interference with small intestinal absorption although the partial response to the gluten-free diet remains unexplained. We are unable to offer any ready explanation of the observed high blood lactate in this child or the increase in lactate after galactose administration.

Support from the Medical Research Council and Wellcome Trust is most gratefully acknowledged. We would also like to thank $\mathrm{Dr}$ M. Worsfold for his help with the preliminary investigations, and Mrs R. Ivings for her skilled technical assistance.
References

Dickens, F., Randle, P. J., and Whelan, W. J. (1968). Carbohydrate Metabolism and its Disorders; Vol. 2. Academic Press, London and New York.

Froesch, E. R. (1966). Essential fructosuria and hereditary fructose intolerance. In The Metabolic Basis of Inherited Disease, edited by J. B. Stanbury, J. B. Wyngaarden, and D. S. Fredrickson, 2nd ed; pp 124-140. McGraw-Hill, New York, Toronto, Sydney, and London.

Gracey, M., Burke, V., and Oshin, A. (1970). Intestinal transport of fructose. Lancet, $2,827-828$.

Gruener, R., McArdle, B., Ryman, B. E., and Weller, R. O. (1968). Contracture of phosphorylase deficient muscle. Neurol. Neurosurg. Psychiat., 31, 268-283.

Hers, H. G., and Joassin, G. (1961). Anomalie de l'aldolase hépatique dans l'intolerance au fructose. Enzym. biol. clin., 1, 4-14.

Köhlin, P., and Melin, K. (1968). Hereditary fructose intolerance in four swedish families. Acta paediat. scand., 57, 24-32.

Ricketts, T. R. (1963). An improved micromethod for the determination of glucose 6-phosphate activity. Clin. chim. acta, 8, 160162. 